УДК 349.3:369.542 (477)

\title{
Ірина Петрівна СИДОР
}

кандидат економічних наук, дочент кафедри фінансів ім. С. І. Юрія, Тернопільський національний економічний університет, Україна, е-таil: irunasudor@gmail.com, ORCID ID: https://orcid.org/0000-0002-4410-7083

\section{ДЕРЖАВНЕ ПЕНСІЙНЕ СТРАХУВАННЯ В УКРАЇНІ: СУЧАСНІ ТЕНДЕНЦІї ТА ВИКЛИКИ}

Сидор, І. П. Державне пенсійне страхування в Украӥні : сучасні тенденщії та виклики // Вісник сочіальноекономічних досліджень : зб. наук. праџьь (ISSN 2313-4569); за ред. М. I. Звєрякова (голов. ред.) та ін. Одеса : Одеський національний економічний університет. 2018. № 2 (66). С. 210-222.

\begin{abstract}
Анотація. У статті розглянуто сутність пенсійного страхування та його необхідність. Проаналізовано вітчизняну практику функиіонування Пенсійного фонду України як основного інституту у сфері державного пенсійного страхування. Визначено тендениії у формуванні доходів бюджету Пенсійного фонду України за останні роки. Вказано причини зростання дефіцитуу бюджету Фонду та збільшення частки закріплених доходів. На основі звітних даних Пенсійного фонду Украӥни проаналізовано напрями використання його коштів, а також співставлено рівень пенсійних виплат основної категорії отримувачів та можливість задоволення за їх рахунок споживчих потреб. Надано оцінку контрольно-аналітичних заходів, проведених органами Пенсійного фонду України в частині здійснення верифікації пенсійних виплат та механізму їх нарахування. Обгрунтовано необхідність реформування пенсійного страхування шляхом реформування солідарної системи, створення накопичувальної системи, розвитку системи добровільного пенсійного забезпечення. Запропоновано запровадити масштабну верифікацію пенсійних виплат по усіх регіонах України з метою достовірності здійснення виплат та економії бюджетних коштів. Водночас, для иьього необхідно узгодити нормативно-правову базу; забезпечити формування єдиної бази даних щзодо отримувачів усіх видів пенсій і ї̈ постійний моніторинг;координувати спільні дї Пенсійного фонду Украӥни, Державної фіскальної служби Украӥни та Державної служби України з питань пращі щзодо виявлення фактів використання праці неоформлених працівників; забезпечити проведення широкої інформаційної діяльності у ЗМI стосовно необхідності здійснення особистих пенсійних накопичень у вигляді відкритих лекиій, обговорень, створення безкоштовних гарячих ліній та ін.
\end{abstract}

Ключові слова: державне пенсійне страхування; пенсійний фонд; державний бюджет; заробітна плата; солідарна пенсійна система; накопичувальна пенсійна система; страховий стаж; верифікація пенсійних виплат; контрольно-перевірочна діяльність; єдиний соціальний внесок.

\section{Ирина Петровна СЫДОР}

кандидат экономических наук, дочент кафедры финансов им. С. И. Юрия, Тернопольский национальный экономический университет, Украина, e-mail: irunasudor@gmail.com, ORCID ID: https://orcid.org/0000-0002-4410-7083

\section{ГОСУДАРСТВЕННОЕ ПЕНСИОННОЕ СТРАХОВАНИЕ В УКРАИНЕ: СОВРЕМЕННЫЕ ТЕНДЕНЦИИ И ВЫЗОВЫ}

Сыдор, И. П. Государственное пенсионное страхование в Украине : современные тенденции и вызовы // Вестник социально-экономических исследований : сб. науч. трудов (ISSN 2313-4569); под ред. М. И. Зверякова (глав. ред.) и др. Одесса : Одесский национальный экономический университет. 2018. № 2 (66). С. 210 -222.

Аннотация. B статье рассмотрена сущность пенсионного страхования и его необходимость. Проанализирована отечественная практика функционирования Пенсионного фонда Украинь как главного института в сфере государственного пенсионного страхования. Определень тенденичи в формировании доходов бюджета Пенсионного фонда Украины за последние годы. Указань причины роста дефицита бюджета Фонда и доли закрепленных доходов. На основе анализа отчетности Пенсионного фонда Украины проанализированы направления использования его средств, а также сопоставлен уровень пенсионных выплат и возможность удовлетворения за их счет потребительских нужд. Дана оченка контрольно-аналитических мероприятий, проведенных органами Пенсионного фонда Украины в части верификации пенсионных выплат и механизма их начисления. Обоснована необходимость реформирования пенсионного страхования путем реформирования солидарной системы, создания накопительной системы, развития системь 
добровольного пенсионного обеспечения. Предложено ввести маситабную верификацию пенсионных выплат по всем регионам Украины с иелью достоверности осуществления выплат и экономии бюджетных средств. В то же время, для этого необходимо согласовать нормативно-правовую базу; обеспечить формирование единой базы данных по получателей всех видов пенсий и ее постоянный мониторинг; координировать совместные действия Пенсионного фонда Украины, Государственной фискальной службы Украины и Государственной службы Украины по вопросам труда по вылвлению фактов использования труда неоформленных работников; обеспечить проведение иирокой информационной деятельности в СМИ о необходимости осуществления личных пенсионных накоплений в виде открытых лекиий, обсуждений, создание бесплатных горячих линий и прочее.

Ключевые слова: государственное пенсионное страхование; пенсионный фонд; государственный бюджет; заработная плата; солидарная пенсионная система; накопительная пенсионная система; страховой стаж; верификация пенсионных выплат; контрольно-проверочная деятельность; единый социиальный взнос.

\title{
Iryna SYDOR
}

PhD in Economics, Associate Professor, Department of Finance named after S. I. Yurii, Ternopol National Economics University, Ukraine, e-mail: irunasudor@gmail.com, ORCID ID: https://orcid.org/0000-0002-4410-7083

\section{STATE PENSION INSURANCE IN UKRAINE: CURRENT TRENDS AND CHALLENGES}

Sydor, I. (2018). State pension insurance in Ukraine: current trends and challenges. Ed.: M. Zveryakov (ed.-in-ch.) and others [Derzhavne pensiine strakhuvannia v Ukraini: suchasni tendentsii ta vyklyky; za red.: M. I. Zveriakova (gol. red.) ta in.], Socio-economic research bulletin; Visnik social'no-ekonomičnih doslidžen' (ISSN 2313-4569), Odessa National Economic University, Odessa, No. 2 (66), pp. 210-222.

\begin{abstract}
The article considers the essence of pension insurance and its necessity. The analysis of the domestic practice of functioning of the Pension Fund of Ukraine as the main institute in the field of state pension insurance is conducted. Trends in the formation of budget revenues of the Pension Fund of Ukraine in recent years are revealed. The reasons for the growth in the budget deficit of the Fund and increase of the share of fixed income are indicated. Based on the analysis of reporting of the Pension Fund of Ukraine, the directions of use of its funds are analyzed, as well as the level of pension payments and the ability to meet the consumer needs are compared. The assessment of the control and analytical measures conducted by the authorities of the Pension Fund of Ukraine with respect to the implementation of the verification of pension payments and the mechanism for their computing is submitted. The necessity of pension insurance reformation through the reforming the solidarity system, creation of the accumulative system, development of the system of voluntary pension provision is substantiated. It is proposed to introduce a large-scale verification of pension payments in all regions of Ukraine in order to verify the reliability of payments and save budget funds. At the same time, it is necessary to harmonize the legal and regulatory framework for this; to ensure the formation of a unified database of the recipients of all types of pensions and its constant monitoring; to coordinate joint actions of the Pension Fund of Ukraine, the State Fiscal Service of Ukraine and the State Service of Ukraine on Labor concerning the fact-finding on the use of labor of undocumented workers; to ensure broad information-related activity in mass media on the need to implement the personal pension savings in the form of open lectures, discussions, creation of toll-free hotlines etc.
\end{abstract}

Keywords: state pension insurance; pension fund; state budget; wages; solidarity pension system; accumulative pension system; insurance period; verification of pension payments; control and verification activities; single social contribution.

JEL classification: E240; E690; G230

Постановка проблеми у загальному вигляді. В умовах побудови громадянського суспільства велике значення має рівень соціального захисту, одним із найважливіших напрямів якого є пенсійне страхування. Ефективність пенсійного страхування в Україні залежить від виконання таких умов: достатність виплати, що означає забезпечення кожного працівника державною пенсією як комбінацією виплат із солідарної та обов'язкової накопичувальної системи; фінансова стабільність, що передбачає фінансову стабільність системи у найближчому і віддаленому майбутньому.

3 переходом України до ринкових умов господарювання виникла соціальна та економічна необхідність докорінних змін в системі державного пенсійного страхування, як 
однієї з важливих гарантій стабільного розвитку суспільства, оскільки зачіпає інтереси як працездатного, так і непрацездатного населення.

Сучасна демографічна ситуація в країні характеризується старінням населення, що призводить до збільшення демографічного навантаження на працездатне населення, зменшенням кількості платників страхових внесків при зростанні чисельності пенсіонерів, нестачею коштів бюджету Пенсійного фонду України. Результатом цього є недостатній для гідного життя рівень пенсій багатьох категорій пенсіонерів, невідпрацьованість системи управління пенсійними ресурсами, недостатня сталість та неадекватність чинної пенсійної системи принципам соціального страхування, соціальна несправедливість системи пенсійного забезпечення. Крім цього, чинна пенсійна система в Україні значною мірою зберігає адміністративно-розподільчий характер, вона не завжди узгоджується із соціальною політикою держави, у зв'язку з чим немає очікуваного ефекту від змін у системі пенсійного страхування [1, с. 249]. Саме тому фінансова нестабільність виявилася одним із головних чинників, що спонукали державу розпочати поступовий перехід від солідарної до трирівневої пенсійної системи, яка передбачає принципи страхування та особистої відповідальності громадян за матеріальне забезпечення своєї старості.

Актуальність теми дослідження обумовлена існуючими проблемами, що накопичуються з року в рік у солідарній системі пенсійного страхування. Так, із 12 млн. пенсіонерів 8 млн. - отримує мінімальну пенсію у розмірі 1489 грн. (з січня 2018 р.), що становить лише близько $50 \%$ від вартості споживчого кошика і це означає, що більшість пенсіонерів живе за межею бідності. Тому, необхідність першочергового проведення широкомасштабної пенсійної реформи є викликом часу.

Одним із пріоритетних завдань пенсійної реформи є підвищення державних гарантій та досягнення більш високих соціальних стандартів у пенсійному забезпеченні громадян. Разом 3 тим, реформована пенсійна система покликана стати потужним джерелом довготривалих інвестицій в економіку, що сприятиме розширенню зайнятості, зростанню доходів громадян та зміцненню фінансової бази пенсійної системи України.

Аналіз досліджень і публікацій останніх років. Існуючі проблеми вітчизняної системи державного пенсійного страхування стали важливим аспектом дослідження вітчизняних вчених та знаходяться в центрі уваги багатьох фахівців, зокрема, вони порушуються у працях: Н. Калити, О. Кириленко, В. Надраги, О. Петрушки, Д. Полозенка, Л. Присяжної, Н. Саінчук, В. Толуб'яка, О. Тулай, С. Юрія тощо. Зокрема, у працях Н. Калити і О. Тулай [2; 3] розглядаються основні проблеми, які виникають в діяльності Пенсійного фонду України та стосується наповнення бюджету ПФУ та можливих альтернативних джерел доходів. Н. Саінчук [4] звертає увагу на пенсійне забезпечення в Україні та необхідність зростання пенсійного віку. В. Надрага [5] зачіпає питання можливих ризиків пенсійної системи України в контексті демографічних викликів. У наукових працях О. Кириленко, О. Петрушки та Д. Полозенка, В. Толуб'яка $[1 ; 6 ; 7 ; 8 ; 9]$ досліджено інституційні основи державного пенсійного страхування в Україні. У праці Л. Присяжної [10] розглянуто перспективи запровадження верифікації соціальних виплат i здійснено аналіз пілотних проектів проведеної верифікації.

Виділення невирішених раніше частин загальної проблеми. Віддаючи належне високому рівню наукових робіт названих авторів, зазначимо, що дослідження теоретичних аспектів, вітчизняної прагматики державного пенсійного страхування мають фрагментарний характер. Об'єктивна необхідність розвитку концептуальних засад, а також потреба в розробках прикладного характеру, спрямованих на удосконалення фінансових та управлінських аспектів державного пенсійного страхування, обумовлюють актуальність теми дослідження та ії доцільність.

Постановка завдання. Метою статті є проведення аналізу вітчизняної практики загальнообов'язкового державного пенсійного страхування, виявлення основних тенденцій і викликів та окреслення основних напрямів його удосконалення в контексті реформування пенсійної системи України. 
Виклад основного матеріалу дослідження. Пенсійне страхування $є$ однією 3 основних гарантій соціального захисту, завданням якого $є$ підтримка матеріального добробуту громадян та їхніх сімей у випадку виходу на пенсію за віком, за інвалідністю чи у випадку втрати годувальника. Разом з тим, пенсійне страхування виступає як сукупність особливих замкнених перерозподільчих відносин між його учасниками 3 питань формування за рахунок грошових внесків цільового пенсійного фонду для надання грошової допомоги громадянам, які вийшли на пенсію. Крім того, пенсійне страхування в умовах товарногрошових відносин може бути використано як метод організації страхового фонду, коли має місце формування централізованого фонду шляхом сплати страхових внесків учасниками та відшкодування витрат із цього фонду тільки серед платників страхових пенсійних внесків.

Таким чином, сутність пенсійного страхування полягає в перерозподілі ризику виникнення страхового випадку між застрахованими 3 однієї сторони і роботодавцями 3 іншої; між поколіннями застрахованих і роботодавців; між застрахованими і роботодавцями, які живуть і працюють в різних регіонах країни, на підприємствах різних галузей. Отже, пенсійне страхування $є$ основою і інструментом державної системи соціального захисту населення, базовим і одним з найбільш важливих соціальних гарантій стабільного розвитку суспільства, оскільки зачіпає інтереси як працездатного, так і непрацездатного населення.

Однією із основних умов стабільного розвитку системи пенсійного страхування $є$ мобілізація грошових коштів та їх акумуляція в бюджеті Пенсійного фонду України, що забезпечує покриття його поточних витрат. Аналіз джерел фінансового забезпечення державного пенсійного страхування дає можливість зробити обгрунтовані висновки про те, в якому обсязі та за рахунок яких джерел відбулося надходження грошових коштів до бюджету Пенсійного фонду та які можливі напрямки їх використання; чи повним i своєчасним є надходження коштів до бюджету фонду.

Основними джерелами формування доходів бюджету ПФУ є: власні надходження, кошти Державного бюджету України, кошти Фондів соціального страхування. Доходи ПФУ у 2016 р. становили 255,8 млрд. грн., що більше ніж у 2014 р. на 12,3 млрд. грн. та менше, ніж у 2015 р. на 8,9 млрд. грн. Зменшення обсягу надходжень коштів обумовлено зниженням розміру ставки ССВ до $22 \%$ та зменшенням частки його розподілу на пенсійне страхування.

Доходи бюджету ПФУ включають власні та закріплені доходи. У період 2014-2015 pp. основу доходів становили власні надходження (64,1-68,1\%), а у 2016 p. - закріплені доходи - 55,7\%, що пов'язано із зростанням дефіциту бюджету ПФУ. Основу власних надходжень ПФУ становить $\mathrm{CCB}$, його частка у структурі власних надходжень складає близько 96\%. Запровадження 22\% ставки ССВ у 2016 р. стало причиною скорочення обсягу надходжень цього платежу, а відтак і скорочення власних надходжень у бюджет ПФУ.

Динаміка надходження коштів Державного бюджету України до бюджету ПФУ вказує на їх зростання на 47,7 млрд. грн. у 2016 р. проти 2015 р., що обумовлено необхідністю компенсації втрат від надходження ССВ. Кількість платників ЄСВ у 2016 р. становила 12,8 млн. осіб, із них 79\% - наймані працівники.

Таким чином, нововведення законодавчої бази призвели до того, що у 2016 р. обсяг надходження ЄСВ суттєво скоротився і становив 111,7 млрд. грн., що менше за аналогічний період попереднього року на 58,1 млрд. грн., питома вага ССВ у структурі доходів бюджету ПФУ склала $41,7 \%$.

У звіті про виконання бюджету Пенсійного фонду України у 2016 р. зазначено, що за умови збереження розміру ССВ на рівні 2015 р. власні доходи ПФУ розрахунково зросли б на 96,4 млрд. грн. [7, с. 138].

За даними Державної фіскальної служби України, на 01.01.2017 р. на обліку перебувало 2270,3 тис. платників ССВ, що на 136,3 тис. платників більше порівняно 3 даними на 01.01.2015 p.

Станом на 01.01.2017 р. у загальній кількості платників:

- юридичних осіб - 511,7 тис. $(23,1 \%)$;

- фізичних осіб-підприємців - 1 758,6 тис. (76,9\%). 
Загальна чисельність застрахованих осіб у грудні 2016 р. склала 12,8 млн. осіб, із яких найманих працівників - 10,1 млн. осіб. У 2016 р. призупинено зменшення кількості застрахованих осіб - найманих працівників. Якщо у 2015 р. їх кількість зменшилась на 66,2 тис. осіб, то у 2016 р. приріст склав 407,1 тис. осіб. Із 10,2 млн. найманих працівників 1238,2 тис. осіб у 2016 р. отримували заробітну плату на рівні або менше мінімальної (1600 грн.), із них близько 222,5 тис. осіб - працівники бюджетної сфери. Чисельність таких працівників збільшилася у 2016 р. порівняно з попереднім роком на 38,8\% (на 325,5 тис. осіб). Заробітну плату менше 3200 грн. у грудні 2016 р. отримувало 4,1 млн. працівників (40,6\% від їх загальної чисельності), в т.ч. у бюджетній сфері 1,1 млн. працівників [11].

Кошти державного бюджету у складі доходів Пенсійного фонду України у 2014 р. становили 31,1\% або 75,8 млрд. грн., а у 2015 р. їх обсяг зріс до 94,8 млрд. грн. або на 19 млрд. грн., що становило 35,8\% усіх доходів бюджету Фонду. У 2016 р. загальний обсяг коштів державного бюджету у складі доходів Фонду зріс на 79,5 млрд. грн., або більше як у два рази (з 94,8 млрд. грн. у 2015 р. до 142,5 млрд. грн. у 2016 р.). Недовиконання планових показників характерно i для коштів державного бюджету, а саме виконання плану надходжень становить лише 98,2\% у 2014 р., у 2015-2016 рр. відмічено 100\% виконання плану. Найбільшу частку в структурі надходжень із державного бюджету до бюджету Пенсійного фонду займає дотація на виплату пенсій, надбавок та підвищень до пенсій, призначених за різними пенсійними програмами, що складає 80,6\%. Окрім того у 2014-2015 pp. із державного бюджету передбачено кошти на покриття дефіциту Пенсійного фонду України для виплати пенсій, в тому числі покриття витрат, пов'язаних 3 обслуговуванням боргових зобов'язань у сумі 14,6 млрд. грн., у наступному 2015 р. сума цих коштів зросла більше як у два рази і становила 31,7 млрд. грн. (табл. 1).

Протягом 2014 року відповідно до статті 43 Бюджетного кодексу України тимчасові касові розриви Пенсійного фонду України, пов'язані з виплатою пенсій, покривалися за рахунок коштів єдиного казначейського рахунку на договірних умовах без нарахування відсотків за користування цими коштами.

Загальний обсяг залучених позик протягом року становив 39,2 млрд. грн. Повернення зазначених коштів відбувалося щомісячно після закінчення виплатного періоду в межах фінансових можливостей Пенсійного фонду України. Залишок неповернутих сум станом на 1 січня 2015 р. склав 969 млн. грн. [1]. У 2016 р. вперше за останні 9 років iз Державного бюджету України позики Пенсійним фондом не залучались. Водночас, зменшено суму непогашених позик, залучених із державного бюджету в попередні роки, на суму 2,4 млрд. грн. У результаті залишок неповернутих сум позик, залучених упродовж 2007-2014 рр., на 01.01.2017 р. скоротився до 48 млрд. грн. [11].

Незначними є обсяги надходження коштів Фондів соціального страхування на випадок безробіття і від нещасних випадків на виробництві. Їх загальний обсяг становив 134,5 млн. грн., що складає менше 1\% усіх доходів бюджету Пенсійного фонду.

Динаміка чисельності пенсіонерів у період 2014-2017 рр. скоротилася на 1577,1 тис. осіб, суттєво їх кількість зменшилася станом на 01.01.2017 р. порівняно 3 попереднім періодом. Як зазначено у звіті Пенсійного фонду України: «... зменшення чисельності одержувачів пенсійних виплат пов'язано 3 призупиненням виплат пенсіонерам із числа внутрішньо переміщених осіб, які згідно з законодавством не звернулися за поновленням виплат на підконтрольній Україні території. Пенсію за Законом України «Про загальнообов'язкове державне пенсійне страхування» фактично отримують 10 876,3 тис. осіб, або 91,1\% загальної чисельності пенсіонерів, із них - 9 101,2 тис. осіб, або 83,7\%, - отримують пенсію за віком» [11, с.22]. Щорічно середній розмір пенсійних виплат зростає, що обумовлено діючими законодавчими актами, зокрема, Законами України про Державний бюджет України на поточний рік, у зв'язку з чим проходять перерахунки пенсій. 
Таблиця 1

Динаміка доходів бюджету Пенсійного фонду України за період 2014-2016 pр., млн. грн.

(складено автором за даними [11])

\begin{tabular}{|c|c|c|c|c|c|c|c|}
\hline \multirow{2}{*}{ Показники } & \multicolumn{2}{|c|}{$2014 \mathrm{p}$} & \multicolumn{2}{|c|}{$2015 \mathrm{p}}$. & \multicolumn{2}{|c|}{$2016 \mathrm{p}$} & \multirow{2}{*}{$\begin{array}{l}\text { Зростання/ } \\
\text { зменшення }\end{array}$} \\
\hline & млн. грн. & $\%$ & млн. грн. & $\%$ & млн. грн. & $\%$ & \\
\hline $\begin{array}{l}\text { Доходи ПФУ, всього, із } \\
\text { них: }\end{array}$ & 243477,9 & 100,0 & 264767,8 & 100,0 & 255801,1 & 100,0 & 12323,2 \\
\hline $\begin{array}{l}\text { Власні надходження, у } \\
\text { тому числі: }\end{array}$ & 165923,3 & 68,1 & 169873,9 & 64,1 & 111706,5 & 43,7 & $-54216,8$ \\
\hline сума ЄСВ на ЗДПС & 159473,0 & 65,5 & 165366,8 & 62,4 & 107148,0 & 41,7 & -52325 \\
\hline $\begin{array}{l}\text { кошти, сплачені банка- } \\
\text { ми за користування } \\
\text { тимчасово вільними } \\
\text { коштами ПФУ }\end{array}$ & 39,0 & - & 61,0 & - & 55,8 & - & 16,8 \\
\hline $\begin{array}{l}\text { кошти на виплату } \\
\text { різниці в пенсійному } \\
\text { забезпеченні наукових } \\
\text { працівників, що відшко- } \\
\text { довуються за рахунок } \\
\text { коштів державних не } \\
\text { бюджетних і недержав- } \\
\text { них підприємств }\end{array}$ & 45,5 & - & 46,0 & - & 46,1 & - & 0,6 \\
\hline $\begin{array}{l}\text { кошти від підприємств } \\
\text { на покриття фактичних } \\
\text { витрат на виплату та } \\
\text { доставку пенсій } \\
\text { (за списком № 1) } \\
\end{array}$ & 2453,8 & 1,0 & 2425,6 & 0,9 & 2572,2 & 1,3 & 1184 \\
\hline $\begin{array}{l}\text { кошти від підприємств } \\
\text { на покриття фактичних } \\
\text { витрат на виплату та } \\
\text { доставку пенсій } \\
\text { (за списком № 2) }\end{array}$ & 1552,4 & 0,6 & 1677,1 & 0,6 & 1662,3 & 0,6 & 109,9 \\
\hline $\begin{array}{l}\text { кошти на виплату } \\
\text { пенсій іноземним } \\
\text { пенсіонерам, які } \\
\text { проживають на } \\
\text { території України }\end{array}$ & 55,8 & - & 82,5 & - & 96,5 & - & 40,7 \\
\hline $\begin{array}{l}\text { кошти фондів соціаль- } \\
\text { ного страхування }\end{array}$ & 2000,0 & 0,9 & - & - & - & - & $-2000,0$ \\
\hline інші надходження & 303,5 & - & 214,6 & - & 125,3 & - & $-178,2$ \\
\hline $\begin{array}{l}\text { Кошти Державного } \\
\text { бюджету України, } \\
\text { всього, у т. ч.: }\end{array}$ & 75813,8 & 31,1 & 94811,5 & 35,8 & 142586,2 & 55,7 & 66772,4 \\
\hline $\begin{array}{l}\text { дотація на виплату } \\
\text { пенсій, надбавок та } \\
\text { підвищень до пенсій, } \\
\text { призначених за різними } \\
\text { пенсійними програмами }\end{array}$ & 61130,6 & 25,1 & 63052,2 & 23,8 & 142586,2 & 55,7 & 81455,6 \\
\hline $\begin{array}{l}\text { покриття дефіциту } \\
\text { коштів ПФУ для } \\
\text { виплати пенсій }\end{array}$ & 14683,2 & 6,0 & 31759,2 & 12,0 & - & - & - \\
\hline
\end{tabular}


Продовження табл. 1

\begin{tabular}{|c|c|c|c|c|c|c|c|}
\hline $\begin{array}{l}\text { Кошти Фонду ЗДСС на } \\
\text { випадок безробіття }\end{array}$ & 67,8 & - & 75,0 & - & 1500,0 & 0,5 & 1394,2 \\
\hline $\begin{array}{l}\text { Кошти Фонду СС від } \\
\text { нещасних випадків на } \\
\text { виробництві та } \\
\text { професійних захворювань }\end{array}$ & 66,7 & - & 7,3 & - & 6,6 & - & $-73,3$ \\
\hline Залишок на початок року & 2405,0 & - & 1767,7 & - & 867,7 & - & $-1332,0$ \\
\hline $\begin{array}{l}\text { Всього доходів з урахуван- } \\
\text { ням залишку коштів на } \\
\text { початок року і позики }\end{array}$ & 245245,6 & - & 266535,5 & - & 256668,8 & - & 11423,2 \\
\hline
\end{tabular}

Середній розмір пенсії по Україні на 1 січня 2017 р. становить 1828,33 грн. проти 1699,51 грн. на 1 січня 2016 р., тобто зріс на 128,82 грн., або 7,6\%. Мінімальна пенсія за віком зросла на 16,1\% (з 1074 грн. на 01.01.2016 р. до 1247 грн. на 01.01.2017 р.). Загалом, за період 2014-2017 рр. середній розмір призначеної пенсії пенсіонерам, які перебувають на обліку в органах Пенсійного фонду України, зросла на 302,2 грн. Якщо розглядати розмір пенсійних виплат за аналізований період в розрізі видів пенсій, то найбільше зростання відбулося в пенсійних виплатах у випадку втрати годувальника, що становить 499,2 грн.

Максимальний розмір пенсій, які призначаються в Україні, становить 10740 грн. Водночас, майже 9 тис. пенсій, призначених до 1 жовтня 2011 р., виплачуються в раніше встановлених розмірах, без обмеження максимальним розміром. Найбільша пенсія, яка виплачується, становить 58764,62 грн. Така пенсія призначена за вислугу років працівнику льотно-випробувального складу, Герою України.

Найбільша чисельність пенсіонерів отримують пенсії, призначені згідно з ЗУ «Про загальнообов'язкове державне пенсійне страхування» - 10876,3 тис. осіб, середній розмір яких становить 1730,77 грн.; за «військовим» законом - 32,8 тис. осіб, розмір пенсій 2745,43 грн., за спеціальними законами отримують пенсії 154,3 тис. осіб, що становить 4010,53 грн.

У табл. 2 представлено динаміку видатків Пенсійного фонду України за період 2014-2016 pp. Так, динаміка видатків бюджету Пенсійного фонду вказує на те, що у 2015 p. сума видатків зросла на 22,2 млрд. грн. порівняно з 2014 р., проте вже у 2016 р. обсяг видатків скоротився до 253,4 млрд. грн. або на 12,2 млрд. грн. (4,6\%). Це зменшення пов'язано, переважно, з призупиненням виплат пенсіонерам з числа внутрішньо переміщених осіб (ВПО). Загалом на пенсійні виплати пенсіонерам з числа ВПО у 2016 р. спрямовано 11,5 млрд. грн., що на 17,9 млрд. грн. менше порівняно з 2015 р. Разом у результаті проведених заходів щодо підтвердження правомірності пенсійних виплат особам з числа ВПО економія коштів Пенсійного фонду України склала 13,5 млрд. грн. [11, с.56]. У загальному обсязі фактичних видатків бюджету ПФУ:

- 111,7 млрд. грн., або 44,0\% - це власні кошти, із яких 3,4 млрд. грн. спрямовано на пенсійні виплати у січні 2017 р.;

- 142,6 млрд. грн., або 56,3\% - це кошти Державного бюджету України, із яких:

- 51,3 млрд. грн. - планові трансферти 3 державного бюджету, із яких 3 млрд. грн. на пенсійні виплати у січні 2017 р.;

- 6,4 млрд. грн. - компенсація Пенсійному фонду страхових внесків за окремі категорії застрахованих осіб;

- 84,9 млрд. грн. - кошти на покриття дефіциту бюджету Пенсійного фонду, із яких 4 млрд. грн. - на авансове фінансування пенсій у січні 2017 p.

Загальний обсяг фактичних видатків, без урахування 10,4 млрд. грн. січневих виплат, склав 93,9\% попередньо затверджених (256,4 млрд. грн.).

На пенсійні виплати спрямовано 249,8 млрд. грн., інші видатки склали 3,6 млрд. грн., iз них - 1,2 млрд. грн. - оплата послуг поштових підприємств 3 виплати і доставки пенсій (0,3\% загальних видатків), 2,4 млрд. грн. - адміністративні видатки (0,9\%). 
Динаміка видатків бюджету Пенсійного фонду України за період 2014-2016 рр. (складено автором за даними [11])

\begin{tabular}{|c|c|c|c|c|c|c|c|}
\hline \multirow{2}{*}{ Показники } & \multicolumn{2}{|c|}{$2014 \mathrm{p}$} & \multicolumn{2}{|c|}{$2015 \mathrm{p}$} & \multicolumn{2}{|c|}{$2016 \mathrm{p}$} & \multirow{2}{*}{$\begin{array}{l}\text { абсолютний } \\
\text { приріст / } \\
\text { зменшення }\end{array}$} \\
\hline & млн. грн. & $\%$ & млн. грн. & $\%$ & млн. грн. & $\%$ & \\
\hline Видатки ПФУ, всього, із них: & 243477,9 & 100,0 & 265667,8 & 100,0 & 253448,5 & 100,0 & 9970,6 \\
\hline за рахунок власних надходжень всього, у тому числі: & 192374,3 & 79,0 & 210766,5 & 79,3 & 202095,6 & 79,7 & 9721,3 \\
\hline $\begin{array}{l}\text { пенсійне забезпечення осіб, пенсія яким призначена згідно із ЗУ «Про } \\
\text { ЗДПС» }\end{array}$ & 181921,7 & 74,7 & 199299,5 & 75,0 & 190638,5 & 75,2 & 8716,8 \\
\hline $\begin{array}{l}\text { пенсійне забезпечення осіб, пенсія яким призначена згідно інших } \\
\text { законодавчих актів в частині, що не перевищує розміру трудової пенсії за } \\
\text { віком }\end{array}$ & 4904,6 & 2,0 & 5299,3 & 2,0 & 4851,3 & 1,9 & $-53,3$ \\
\hline $\begin{array}{l}\text { виплата різниці у пенсійному забезпеченні наукових працівників, що } \\
\text { відшкодовується за рахунок коштів державних не бюджетних та } \\
\text { недержавних підприємств та установ }\end{array}$ & 84,1 & 0,03 & 82,5 & 0,03 & 72,8 & 0,025 & $-11,3$ \\
\hline $\begin{array}{l}\text { виплата доплати відповідно до 3У «Про поліпшення матеріального } \\
\text { становища учасників бойових дій та інвалідів війни» }\end{array}$ & 93,7 & 0,038 & 93,3 & 0,038 & 79,9 & 0,025 & $-13,8$ \\
\hline $\begin{array}{l}\text { пенсійне забезпечення військовослужбовців, осіб начальницького та } \\
\text { рядового складу в частині, що не перевищує розмір трудової пенсії }\end{array}$ & 2958,1 & 1,2 & 3440,6 & 1,3 & 3840,5 & 1,5 & 882,4 \\
\hline $\begin{array}{l}\text { пенсійне забезпечення осіб, які проживають за кордоном та іноземних } \\
\text { пенсіонерів }\end{array}$ & 88,6 & 0,03 & 123,2 & 0,04 & 145,9 & 0,05 & 57,3 \\
\hline розрахунково-касове обслуговування у сфері пенсійного забезпечення & 84,0 & 0,03 & 73,5 & 0,025 & 68,7 & 0,02 & $-15,3$ \\
\hline керівництво та управління у сфері пенсійного забезпечення & 2163,9 & 0,9 & 2243,5 & 0,8 & 2397,5 & 0,9 & 233,6 \\
\hline виготовлення пенсійних посвідчень та документів & 1,8 & - & 2,1 & - & - & - & - \\
\hline $\begin{array}{l}\text { виготовлення бланків, виплатних відомостей для виконання функцій } 3 \\
\text { призначення та виплати пенсій }\end{array}$ & 34,3 & 0,01 & 39,7 & - & - & - & - \\
\hline $\begin{array}{l}\text { створення програмно-технічного забезпечення системи інформаційно- } \\
\text { аналітичної підтримки органів ПФУ }\end{array}$ & 38,9 & 0,01 & 69,0 & 0,02 & - & - & - \\
\hline За рахунок коштів Державного бюджету України, всього, в тому числі: & 50957,2 & 20,9 & 54832,8 & 20,6 & 51344,9 & 20,2 & 387,7 \\
\hline $\begin{array}{l}\text { виплату пенсій, надбавок та підвищень до пенсій, призначених за різними } \\
\text { пенсійними програмами }\end{array}$ & 50957,2 & 20,9 & 54832,8 & 20,6 & 51343,5 & 20,2 & 387,7 \\
\hline $\begin{array}{l}\text { на компенсацію роботодавцю частини фактичних витрат, пов'язаних із } \\
\text { сплатою ЄСВ на ЗДПС }\end{array}$ & - & - & - & - & 1,4 & - & - \\
\hline За рахунок коштів Фонду ЗДСС на випадок безробіття & 75,0 & - & 68,3 & - & 6,5 & - & $-68,5$ \\
\hline $\begin{array}{l}\text { За рахунок коштів Фонду СС від нещасних випадків на виробництві та } \\
\text { професійних захворювань }\end{array}$ & 71,3 & - & - & - & - & - & - \\
\hline Залишок на кінець року & 1767,7 & - & 867,7 & - & 870,0 & - & $-897,7$ \\
\hline Всього видатків з урахування залишку коштів на кінець року & 245245,6 & - & 266535,5 & - & 260000,3 & - & 14754,7 \\
\hline
\end{tabular}


За результатами проведеного дослідження можна зробити висновок про те, що у 2016 р. відбулося скорочення багатьох видатків бюджету Пенсійного фонду, які здійснювалися за рахунок власних коштів, окрім: виплати пенсій (зросла на 8,7 млрд. грн. порівняно з 2014 р.); пенсійного забезпечення військовослужбовців (зростання відбулося на 0,9 млрд. грн.); пенсійне забезпечення осіб, які проживають за кордоном (+ 0,05 млрд. грн.) та видатки на керівництво і управління (+ 0,2 млрд. грн.).

Пенсійний фонд України є органом, основною метою діяльності якого є: керівництво та управління солідарною системою пенсійного страхування; проведення контролю за ефективним та цільовим використанням коштів бюджету Пенсійного фонду; здійснення адміністративного управління накопичувальним фондом; проведення своєчасного збору, акумуляції та обліку страхових внесків і зборів; призначення пенсійних виплат та підготовка відповідних документів для їх виплати; забезпечення повного і своєчасного фінансування виплати пенсій; вирішення питань, щодо ведення обліку пенсійних активів на накопичувальних пенсійних рахунках застрахованих осіб; виконання інших функцій, передбачених відповідним Законом та статутом Пенсійного фонду. Відтак, оцінку контрольно-аналітичної діяльності органів ПФУ доцільно здійснювати за такими напрямами:

- участь у проведенні верифікації стосовно чисельності пенсіонерів та розрахунку пенсійних виплат;

- проведення контролю за цільовим і ефективним використанням коштів та визначення заборгованості зі сплати платежів до ПФУ;

- проведення внутрішнього аудиту органами ПФУ.

Світовий банк і МВФ щороку у своїх рекомендаціях і програмах співробітництва 3 Україною наголошують на необхідності переходу на адресне надання державних соціальних виплат. Міністерство фінансів України повідомило про намір розпочати у 2016 р. аудит і верифікацію соціальних виплат, i їх одержувачів для оптимізації системи соціального захисту та соціального забезпечення громадян. Обсяг соціальних витрат, який підлягає ревізії, складав - 363 млрд. грн. Верифікація передбачає виявлення шахрайських схем нелегального отримання соціальної допомоги. Процес верифікації не передбачає штрафи, а лише виключно аналіз даних, отриманих з офіційних джерел. Утім, у випадку виявлення відхилень Міністерство фінансів повідомить про це Міністерство соціальної політики або Пенсійний фонд України (ПФУ). Після цього органи соціального захисту або ПФУ приймуть рішення щодо припинення виплат чи допомоги або звернуться до суду із позовом про стягнення отриманих незаконно сум.

У випадку, якщо особи організовують схеми 3 отримання виплат в обхід законодавства, передбачена кримінальна відповідальність: за шахрайство (ст. 190 КК) i підробку документів (ст. 358) можна понести покарання терміном на 12 років.

Водночас, на думку міністра соціальної політики України П. Розенка, є зворотня сторона медалі - невиплачені борги Пенсійного фонду, за які після верифікації доведеться розраховуватися державі. «На даний момент вступили в силу, але не виконані судові рішення, згідно з якими Пенсійний фонд повинен виплатити людям борги на суму 4,5 млрд. грн. (переважно чорнобильцям, дітям війни та іншим категоріям). Говорити, що верифікація - тільки економія, невірно», - вважає міністр [10].

Загалом процес верифікації передбачає проходження кількох етапів. Насамперед необхідно звірити реєстри та списки, що перебувають у розпорядженні кількох міністерств $\mathrm{i}$ відомств - Міністерства соціальної політики, Міністерства юстиції, Міграційної служби тощо.

Другий крок верифікації передбачає перевірку достовірності документів: чи має людина право отримувати підвищену пенсію або певні доплати до неї. Причому перевірка стосуватиметься не лише пенсій, але й субсидій 3 комунальних платежів, а саме коректності заповнення форми заяви. Окрім того, Міністерство фінансів отримало право перевіряти банківські рахунки громадян, які отримують пенсії та соціальні виплати відповідно до Закону України № 3629 «Про внесення змін до Бюджетного кодексу України (щодо узгодження норм Бюджетного кодексу зі змінами до галузевого та податкового 
законодавства)» [12], який передбачає доступ Міністерства фінансів України до банківської таємниці. Зазначене продиктовано необхідністю виявляти випадки, коли гроші нараховуються одній людині, а потрапляють на рахунки іншої, або ж якщо карткою, на яку нараховується соціальна допомога або пенсія, користується не та людина, якій вона видана.

Варто зазначити, що впровадження системи верифікації, розробленої Міністерством фінансів, загалом потребувало створення нормативної бази для функціонування процесу верифікації соціальних виплат та пенсій. Так, у грудні 2015 р. за ініціативою Міністерства фінансів Верховна Рада України ухвалила зміни до законодавства, що створюють підгрунтя для проведення верифікації всіх отримувачів соціальних виплат та допомоги від держави.

На сьогоднішній день програма верифікації соціальних виплат працює в пілотному режимі. Утім, варто зазначити, що Міністерство соціальної політики спільно із СБУ проводять активну роботу щодо перекриття схем незаконного отримання пенсій та інших соціальних виплат. Зокрема, у 2016 р. близько 1 млн. 100 тис. пенсіонерів були зареєстровані як внутрішньо переміщені особи. У результаті перевірки міністерство припинило виплати приблизно 180 тис. осіб, з яких 22 тис. осіб померли, а ще для 150 тис. осіб кошти перестали виплачувати на підставі отриманої від СБУ і поліції інформації про те, що ці пенсіонери не проживають за вказаними адресами [10].

За даними Державної служби статистики України, більше 4 млн. осіб, або кожен 4 працівник, працюють без оформлення трудових відносин (показник неформальної зайнятості населення становить 24,6\%). Найбільше таких працівників у сільському господарстві $(41,1 \%)$, торгівлі $(21,1 \%)$, будівництві $(14,9 \%)$, промисловості $(6,0 \%)$ та транспорті (3,6\%). Внаслідок неформальної зайнятості втрати Пенсійного фонду на рік розрахунково становлять понад 30 млрд. грн. У зв'язку з цим органами Пенсійного фонду забезпечується моніторинг мінімізації страхувальниками доходів працівників та сплати ССВ, вживаються відповідні заходи реагування. Зокрема, у квітні 2016 р. Пенсійним фондом України, Державною службою України з питань праці, Державною фіскальною службою України затверджено План заходів щодо координації спільних дій 3 виявлення фактів використання праці неоформлених працівників [11, с.64].

За результатами проведеної роботи, у 2016 р. легалізовано 193,8 тис. робочих місць, у результаті чого мобілізовано 159,6 млн. грн. ССВ. Крім того, за матеріалами моніторингу надано інформацію: органам Державної служби України 3 питань праці - по 190,6 тис. страхувальників (у яких працює 1270 тис. застрахованих осіб), які порушують законодавство про працю. За результатами реагування, виявлені порушення у 2,6 тис. страхувальників по 54,2 тис. застрахованих осіб; органами Державної фіскальної служби України - по 70,8 тис. страхувальників, у яких працює 179,3 тис. застрахованих осіб. У результаті чого підтверджено порушення законодавчих вимог у 3,4 тис. страхувальників по 9,4 тис. застрахованих осіб. Внутрішній аудит діяльності органів ПФУ виявив низку недоліків щодо нарахування і виплати пенсій окремим категоріям пенсіонерів, внаслідок чого зекономлено 16,3 млн. грн. коштів Фонду. Органами ПФУ у 2016 р. подано 11,6 тис. позовів до суду на суму 2,1 млрд. грн.

Висновки і перспективи подальших розробок. Таким чином, діяльність Пенсійного фонду України в сучасних умовах диктує низку викликів, які в умовах пенсійної реформи потребують подальшого удосконалення 3 метою ліквідації тіньових схем нелегального отримання пенсійних виплат та необхідності легалізації заробітних плат, що у подальшому обумовить зростання надходжень $\mathrm{CCB}$, а відтак, і доходів Пенсійного фонду. Аналіз вітчизняної практики державного пенсійного страхування доводить, що ефективність іiі функціонування є вкрай низькою. Це зумовлено такими негативними факторами:

1) незадовільний макроекономічний стан, що проявляється у дефіциті бюджету Пенсійного фонду, який не повною мірою забезпечує фінансування пенсій за рахунок власних джерел [2, с.10];

2) погіршення демографічної ситуації, старіння населення і необхідність збільшення обсягу коштів для їх забезпечення веде до зростання пенсійного навантаження на населення працездатного віку [3, с.134; 8, с.18]; 
3) співвідношення чисельності отримувачів пенсій і платників внесків до Пенсійного фонду наблизилася до критичної межі, що свідчить про неможливість пенсійного забезпечення при збереженні такого співвідношення [4, с.82];

4) нестабільність законодавчої бази (постійне внесення змін до чинного законодавства, перерахунки пенсій, пов'язані зі зміною законодавчо-нормативної бази);

5) економічно необгрунтований порядок встановлення таких державних соціальних стандартів як: прожитковий мінімум, мінімальна заробітна плата (встановлення мінімального розміру пенсії на рівні прожиткового мінімуму для осіб, які втратили працездатність, викликає зрівнялівку у пенсійному забезпеченні, підвищення соціальної напруги у суспільстві, нівелює роль трудового стажу) [5, с.82; 6, с.92];

6) не повною мірою відповідає реаліям сьогодення нова формула розрахунку пенсій, оскільки індивідуальний коефіцієнт заробітку розраховується як відношення заробітної плати, з якої сплачені страхові внески, до середньої заробітної плати по Україні за останні три роки. 3 однієї сторони, позитивним моментом $є$ врахування у формулі розрахунку трудового стажу і заробітку майбутнього пенсіонера, проте доволі суперечливим моментом при розрахунку пенсії є визначення середньої заробітної плати за останні 3 роки, а не як це було раніше, на вибір особи будь-які три роки з іï трудового стажу. Адже відомо, що продуктивність праці, а, відповідно і заробіток, у перед пенсійному віці є не високим, а відтак - це знижує обсяг нарахованої пенсії. До того ж, на сьогодні пенсії призначаються 3 урахуванням середньої заробітної плати за 2014-2016 pp. у розмірі 3764 грн. при цьому середній розмір заробітної плати по Україні станом на 01.10.2017 р. становив 7377 грн., що майже у два рази більше [11]. Також парадоксальна ситуація, коли при розрахунку пенсії у 2017 р. береться до уваги показник середньої заробітної плати за попередні три роки без відповідного коригування на рівень інфляції (індекс споживчих цін).

Отже, вплив вищезгаданих чинників розбалансував пенсійну систему, вона втратила свою фінансову рівновагу, а процес пенсійного реформування свою демократичність. Саме тому, головною метою реформи чинної солідарної системи пенсійного забезпечення $\epsilon$ :

- підвищити розмір заробітної плати та інших доходів населення. У сучасних умовах рівень заробітної плати працівників не повною мірою відповідає вартості робочої сили. Заробітна плата працівників повинна надавати їм можливість не тільки сплачувати податки й страхові внески, підвищувати рівень споживання, але й робити відповідні заощадження в банківських установах, формуючи тим самим фінансові ресурси для інвестування національної економіки;

- стимулювання працюючого населення до сплати єдиного внеску із легальної заробітної плати та визначення внутрішніх джерел для того, аби солідарна система була самодостатньою;

- здійснювати розрахунок величини прожиткового мінімуму, на рівні якого встановлюють розмір мінімальної пенсії, використовуючи реальні ціни на товари та послуги мінімального споживчого бюджету (переглянути перелік товарів та послуг, що становлять мінімальний споживчий бюджет відповідно до реалій часу);

- стимулювання підвищення рівня життя населення, що сприятиме продовженню тривалості його життя і на цій основі створення передумов для підвищення пенсійного віку;

- формування зацікавленості серед усіх верств населення щодо пенсійного накопичення. Широка інформаційна політика про необхідність особистих пенсійних накопичень у засобах масової інформації, проведення відкритих лекцій, обговорень, створення безкоштовних гарячих ліній.

Оскільки в Україні сьогодні наявний вплив як інфляційних чинників, так i демографічних, а крім того, відчувається серйозна нестача інвестиційних ресурсів, можна зробити висновок, що пенсійна система України має включати елементи як солідарної, так і накопичувальної систем. Тому вибір Україною трирівневої моделі як основи для реформування чинної пенсійної системи можна вважати досить зваженим. Вона дозволить розподілити між трьома іiї складовими ризики, пов'язані зі змінами у демографічній ситуації, 
яка стає все гострішою, з коливаннями в економіці та на ринку капіталів. Це зробить пенсійну систему фінансово збалансованішою та стійкішою, застрахує працівників від зниження загального рівня доходів після виходу на пенсію.

Основою реформованої пенсійної системи має стати перехід від пенсійного забезпечення до системи пенсійного страхування, що грунтується на залежності розміру пенсії від заробітку та перерахованих страхових внесків до системи пенсійного страхування. Перші кроки в цьому напрямі вже зроблено при ухваленні змін до Закону України «Про загальнообов'язкове державне пенсійне страхування» від 01.10.2017 p. [13] та затвердженні Стратегії модернізації та розвитку ПФУ на період до 2020 р. [9]. Разом $з$ тим, реформуванням солідарної системи неможливо розв'язати всі проблеми діючої пенсійної системи забезпечення іiі соціальної справедливості, економічної обгрунтованості та фінансової стабільності неодмінно вимагає запровадження обов'язкової накопичувальної системи (другий рівень).

Поєднання солідарної і накопичувальної системи $є$ найоптимальнішим варіантом, оскільки дозволяє диверсифікувати різні типи ризиків і забезпечити основні види пенсій. Найбільша вада розподільчої системи полягає у тому, що вона не дає ніяких гарантій виплати ані сьогодні, ані в майбутньому. У свою чергу, накопичувальна система забезпечує високий рівень гарантій виплати пенсій для учасників, як в даний час, так і в перспективі (при ліквідації пенсійного фонду активи розподіляються пропорційно до обсягу накопичених пенсійних прав учасників).

Перспективи подальших досліджень у сфері державного пенсійного страхування передбачають розробку питань щодо мінімізації ризиків при нарахуванні та виплаті пенсій в частині удосконалення їх програмного забезпечення, а також оцінки контрольно-аналітичної діяльності Пенсійного фонду України.

\section{Jimepamypa}

1. Соціальне страхування : навч. посіб. / За заг. ред. О. П. Кириленко, В. С. Толуб'яка. Тернопіль : Економічна думка, 2016. 353 с.

2. Калита Н. В. Система пенсійного забезпечення в Украӥні : необхідність і основні напрями реформування // Вісник Київського наџіонального університету ім. Т. Шевченка. Серія : Економіка. 2009. Вип. 47. С. 7-11.

3. Тулай О. І. Актуальні проблеми діяльності Пенсійного фонду Украйни // Проблеми економіки. 2016. № 1. С. 132-139.

4. Саінчук Н. В. Стан та перспективи розвитку системи пенсійного забезпечення $в$ Украӥні // Науковий вісник Чернівецького університету. 2014. Вип. 681. Економіка. С. 79-84.

5. Надрага В. І. Фінансові ризики розбудови пенсійної системи в Украӥні : демографічний аспект // Фінанси України. 2015. № 1. С. 79-86.

6. Кириленко О., Петрушка О. Інституиійні основи державного пенсійного страхування в Україні // Журнал європейської економіки. 2013. Т. 12. № 1. С. 79-95.

7. Петрушка О. Шляхи удосконалення практики мобілізаџіï доходів Пенсійного фонду Украӥни // Науковий вісник Херсонського державного університету. Серія : Економічні науки. 2016. Вип. 16. С. 136-139.

8. Полозенко Д. В. Розвиток пенсійної системи України // Фінанси Украӥни. 2010. № 10. C. $15-19$.

9. Про схвалення Стратегії модернізащії та розвитку Пенсійного фонду України на період до 2020 р. : Розпорядження Кабінету Міністрів України № 672-p від 14.09.2016 p. URL: http://zakon3.rada.gov.ua/laws/show/672-2016-p (дата звернення: 12.04.2018).

10. Присяжна Л. Верифікачія сочіальних виплат // Центр досліджень сочіальних комунікаџій НБУВ. URL: http://nbuviap.gov.ua/index.php?option=com (дата звернення: 18.04.2018).

11. Інформаційно-аналітичні матеріали до звіту про виконання бюджету Пенсійного фонду України за 2014-2016 роки // Пенсійний фонд України. URL: https://www.pfu.com.ua/news/ 2015/01/3/616 (дата звернення: 25.04.2018). 
12. Бюджетний кодекс України : Закон Украӥни, Кодекс № 2456-VI від 08.07.2010 p. URL: http://zakon4.rada.gov.ua/laws/show/2456-17 (дата звернення:25.04.2018).

13. Про загальнообов'язкове державне пенсійне страхування : Закон України № 1058-IV від 09.07.2003 p. URL: http://zakon5.rada.gov.ua/laws/show/1058-15/page (дата звернення: 25.04.2018).

\section{References}

1. Social insurance. Ed. by O. P. Kyrylenko, V. S. Tolubyak [Sotsialne strakhuvannia; za red. O. P. Kyrylenko, V. S. Tolubiaka], Ekonomichna dumka, Ternopil, 353 s. [in Ukrainian]

2. Kalyta, N. V. (2009). System of pension provision in Ukraine: necessity and main directions of reforming [Systema pensiinoho zabezpechennia v Ukraini: neobkhidnist $i$ osnovni napriamy reformuvannia], Visnyk Kyivskoho natsionalnoho universytety im. T. Shevchenka, Seriia: Ekonomika, Vyp. 47, s. 7-11 [in Ukrainian]

3. Tulai, O. I. (2016). Actual problems of the activity of the Pension Fund of Ukraine [Aktualni problemy diialnosti Pensiinoho fondu Ukrainy], Problemy ekonomiky, No. 1, s. 132-139 [in Ukrainian]

4. Sainchuk, N. V. (2014). State and prospects of the development of the pension system in Ukraine [Stan ta perspektyvy rozvytku systemy pensiinoho zabezpechennia $v$ Ukraini], Naukovyi visnyk Chernivetskoho universytetu, Vyp. 681, Ekonomika, s. 79-84 [in Ukrainian]

5. Nadraga, V. I. (2015). Financial risks of pension system development in Ukraine: the demographic aspect [Finansovi ryzyky rozbudovy pensiinoi systemy v Ukraini: demohrafichnyi aspect], Finansy Ukrainy, No. 1, s. 79-86 [in Ukrainian]

6. Kyrylenko, O. P., Petrushka, O. V. (2013). Institutional foundations of state pension insurance in Ukraine [Instytutsiini osnovy derzhavnoho pensiinoho strakhuvannia v Ukraini], Zhurnal yevropeiskoi ekonomiky, T. 12, No. 1, s. 79-95 [in Ukrainian]

7. Petrushka, O. (2016). Ways to improve the practice of mobilizing the revenues of the Pension Fund of Ukraine [Shliakhy udoskonalennia praktyky mobilizatsii dokhodiv Pensiinoho fondu Ukrainy], Naukovyi visnyk Khersonskoho derzhavnoho universytetu, Seriia: Ekonomichni nauky, Vyp. 16, s. 136-139 [in Ukrainian]

8. Polozenko, D. V. (2010). Development of pension system of Ukrane [Rozvytok pensiinoi systemy Ukrainy], Finansy Ukrainy, No. 10, s. 15-19 [in Ukrainian]

9. On approval of modernization and development strategy of the Pension Fund of Ukraine until 2020: Law of Ukraine, No. 672-p, 14.09.2016 [Pro skhvalennia Stratehii modernizatsii ta rozvytku Pensiinoho Fondu Ukrainy na period do 2020 r.: Rozporiadzhennia Kabinetu Ministriv Ukrainy, No. 672-p, 14.09.2016], available at: http://zakon3.rada.gov.ua/laws/show/ 672-2016-p [in Ukrainian]

10. Prysiazhna, L. Verification of social benefits [Veryfikatsiia sotsialnykh vyplat], Tsentr doslidzhen sotsialnykh komunikatsii NBUV, available at: http://nbuviap.gov.ua/index.php ?option=com [in Ukrainian]

11. Information and analytical materials to the report on implementation of the budget of the Pension Fund of Ukraine for 2014-2016 [Informatsiino-analitychni materialy do zvitu pro vykonannia biudzhetu Pensiinoho fondu Ukrainy za 2014-2016 rr.], Pensiinyi fond Ukrainy, available at: https://www.pfu.com.ua/news/2015/01/3/616 [in Ukrainian]

12. The Budget Code of Ukraine: Law of Ukraine, No. 2456-VI, 08.07.2010 [Biudzhetnyi Kodeks Ukrainy: Zakon Ukrainy, Kodeks No. 2456-VI, 08.07.2010], available at: http://zakon4.rada.gov.ua/laws/show/2456-17 [in Ukrainian]

13. On mandatory state pension insurance: Law of Ukraine, No. 1058-IV, 09.07.2003 [Pro zahalnooboviazkove derzhavne pensiine strakhuvannia: Zakon Ukrainy, No. 1058-IV, 09.07.2003, available at: http://zakon5.rada.gov.ua/laws/show/1058-15/page [in Ukrainian] 